\title{
Rasio Jenis Kelamin dan Tingkat Kematangan Gonad pada Rajungan (Portunus pelagicus) Linnaeus, 1758 (Malacostraca:Portunidae) yang Didaratkan di Kelurahan Pacar, Kabupaten Rembang
}

\author{
Sri Devi Simanjuntak*, Ervia Yudiati, Subagiyo \\ Departemen IImu Kelautan, Fakultas Perikanan dan IImu Kelautan, Universitas Diponegoro \\ Jl. Prof H.Soedharto S H, Tembalang, Semarang, Jawa Tengah 50275 Indonesia \\ *Corresponding author, e-mail : sridevisimanjuntak28@gmail.com
}

\begin{abstract}
ABSTRAK : Rajungan (Portunus pelagicus) memiliki nilai ekonomi tinggi, dimana berbanding lurus dengan penangkapan yang meningkat. Tingkat pemanfaatan yang tidak mengindahkan ukuran dan kondisi rajungan dapat mempengaruhi struktur ukuran dan stok rajungan di suatu perairan. Penelitian ini bertujuan untuk melakukan kajian morfometri, rasio jenis kelamin dan tingkat kematangan gonad rajungan yang didaratkan di Kelurahan Pacar, Kabupaten Rembang. Metode yang digunakan dalam penelitian bersifat deskriptif dan eksploratif. Pengamatan rajungan dilakukan pada salah satu pengepul di Kelurahan Pacar. Rajungan yang diteliti berdasarkan morfometri, rasio seksual dan tingkat kematangan gonad selama 30 hari. Informasi ini dapat dijadikan pedoman dalam menentukan kebijakan mengenai pengelolaan perikanan rajungan yang berkelanjutan. Hasil dari penelitian diketahui bahwa ratio kelimpahan rajungan jantan sebesar $45 \%$ (1342 ekor); rajungan betina 55\% (1658 ekor) dari 3000 ekor sampel rajungan. Rasio perbandingan jantan dan betina 0,80:1 berdasarkan uji chi square. Berdasarkan distribusi ukuran lebar karapas rajungan di perairan Kelurahan Pacar adalah berkisar antara 60-179 mm dan distribusi berat sebesar 23-251 gram. Distribusi tingkat kematangan gonad pada perairan Kelurahan Pacar adalah 558 ekor pada TKG 1; 761 ekor pada TKG 2; dan 339 pada TKG 3. Data menunjukkan bahwa pola pertumbuhan rajungan yang ada di perairan Kelurahan Pacar adalah allometrik negatif yaitu pertumbuhan lebar karapas lebih cepat bertambah daripada berat tubuhnya baik rajungan jantan maupun rajungan betina.
\end{abstract}

Kata Kunci : Morfometri; Rasio Jenis Kelamin; Tingkat Kematangan; Gonad

\section{Sexual Ratio and maturity Gonad Blue Swimming Crab (Portunus pelagicus) Linnaeus, 1758 (Malacostraca:Portunidae) Pacar Village, Rembang Regency}

\begin{abstract}
Blue swimming crab (Portunus pelagicus) has a high economic value, which is causing the crab catch to rise as well. The catch rate that does not consider the size and maturity of sea crab can affect the size structure and population stock of sea crab in waters. This research to study morphometry, sexual ratio and maturity level of the gonads landed in Pacar Village, Rembang Regency. The method used in this study descriptive and exsplorative. Observation of blue swimming crab samples was carried out in one of the collectors in the village. Blue swimming crab was observed based on morphometry and sexual ratio for 30 days. The results of the study revealed that the abundance of male blue swimming crab was 45\% (1342 male blue swimming crabs) and the abundance of the female blue swimming crabs was 55\% (1658 female blue swimming crabs) of 3000 blue swimming crab samples. The ratio of male and female $0.80 ; 1$ based on the chi square. Based on the size distribution of the width of the blue swimming crab carapace in the waters of Pacar Village it range from $60-179 \mathrm{~mm}$ and the distribution of weight 23251 grams. The distribution of gonad maturity level in the waters Pacar Village is 558 female blue swimming crab at TKG 1; 761 female blue swimming crab at TKG 2; and 339 female blue swimming crab at TKG 3. Data is showed that the blue swimming crab growth pattern in Pacar Village waters was negative allometric both male and female blue swimming crab.
\end{abstract}

Keywords: Morphometry; Sexual Ratio; Maturity level; gonad 


\section{PENDAHULUAN}

Rajungan (Portunus pelagicus) merupakan salah satu hasil tangkapan ekonomis penting bagi nelayan di Kelurahan Pacar, karena memiliki harga jual yang cukup tinggi. Jumlah penangkapan Rajungan di alam semakin meningkat dan berdampak pada penurunan terhadap sumberdaya Rajungan setiap tahunnya. Sampai saat ini seluruh kebutuhan ekspor Rajungan masih mengandalkan dari hasil tangkapan di alam (Juwana et al., 2009). Badan Pusat Statistik (2017) melaporkan bahwa, Rajungan diekspor kebeberapa negara seperti Singapura, Hongkong, Jepang, Malaysia, Taiwan, dan Amerika Serikat dengan harga jual yang tinggi dan target pasar yang luas. Tahun 2015 nilai ekspor kepiting rajungan mencapai USD 310 juta, dan terus meningkat pada tahun 2016 yakni mencapai USD 322 juta. Bahkan pada tahun 2017 nilai ekspor rajungan lebih meningkat lagi yaitu mencapai USD 411 juta.

Aktivitas penangkapan Rajungan Portunus pelagicus secara terus menerus akan berimbas terhadap aspek reproduksi, yaitu ukuran rajungan yang masih kecil akan mengalami matang gonad lebih cepat. Penangkapan rajungan yang telah dilakukan secara intensif akan berpengaruh kepada aspek biologi reproduksi rajungan. Untuk itu perlu dilakukan kajian tentang ukuran dan kondisi reproduksi Rajungan yang tertangkap, apakah sudah sesuai dengan peraturan yang telah ditetapkan. Untuk menjaga kelestarian Rajungan di Perairan Kelurahan Pacar, Kabupaten Rembang diperlukan pengelolaan berkelanjutan serta dibutuhkan informasi melalui penelitian tersebut. Penelitian ini bertujuan untuk mengetahui tingkat penangkapan rajungan berdasarkan morfometri, rasio jenis kelamin dan tingkat kematangan gonad (TKG) di Kelurahan Pacar, Kabupaten Rembang.

\section{MATERI DAN METODE}

Penelitian di Perairan Rembang Kelurahan Pacar, Kabupaten Rembang (Gambar 1). Materi penelitian meliputi sampel 3000 ekor Rajungan ( $P$. pelagicus) yang tertangkap selama penelitian dari salah satu pengepul di Kelurahan Pacar, Kabupaten Rembang. Metode yang digunakan dalam penelitian ini adalah metode survey yang bersifat deskriptif. Pengambilan sampel rajungan dilakukan dengan metode purposive method sampling. Sampel rajungan diambil kurang lebih 100 individu dari hasil tangkapan nelayan yang telah disetor ke pengepul. Data pengukuran sampel rajungan meliputi berat total, panjang dan lebar karapas. Rajungan dapat diidentifikasi jenis kelaminnya dari warna karapas dan bentuk abdomennya (de Lestang et al., 2003). Penentuan TKG dengan cara morfologi didasarkan pada bentuk, ukuran panjang, berat, warna dan perkembangan gonad (Asosiasi Pengelolaan Rajungan Indonesia, 2017). Penentuan lokasi parameter lingkungan diamati secara in situ di lapangan dengan pertimbangan penentuan oleh nelayan berdasarkan perwakilan wilayah tangkapan. Penentuan lokasi penangkapan rajungan ini menggunakan alat bantu GPS yang telah ditentukan oleh nelayan berdasarkan daerah penangkapan rajungan diperairan tersebut.

Hubungan antara lebar dan berat tubuh dihitung dengan rumus menurut Kamrani et al. (2010). Pada selang kepercayaan $95 \%$ bandingkan nilai $T$ hitung dengan nilai $T$ tabel kemudian keputusan yang diambil untuk mengetahui pola pertumbuhan yaitu : $T_{\text {hitung }}>T_{\text {tabel }}$ : tolak hipotesis nol $\left(\mathrm{H}_{0}\right), \mathrm{T}_{\text {hitung }}<\mathrm{T}_{\text {tabel }}$ : terima hipotesis nol $\left(\mathrm{H}_{0}\right)$.

Menurut Tuhuteru dan Chodrijah (2018), untuk mengetahui keseimbangan nisbah kelamin menggunakan uji Chi-Square. Pada selang kepercayaan 95\% dibandingkan antara $\mathrm{X}^{2}{ }_{\text {hitung }}$ dengan $X_{\text {tabel }}$ kemudian keputusan yang diambil untuk mengetahui keseimbangan nisbah kelamin yaitu : $X^{2}$ hitung $>X_{\text {tabel }}$ : Nisbah kelamin jantan dan betina tidak seimbang; $X^{2}$ hitung $<X_{\text {tabel }}$ : Nisbah kelamin jantan dan betina seimbang; $X^{2}$ nitung $=X_{\text {tabel }}$ : Nisbah kelamin jantan dan betina seimbang.

Analisis tingkat kematangan gonad berupa distribusi tingkat kematangan gonad rajungan betina menggunakan software Microsoft excel. Distribusi diicari dengan menghitung jumlah rajungan betina pada setiap tingkat kematangan gonad kemudikan disajikan dalam diagram lingkaran. 


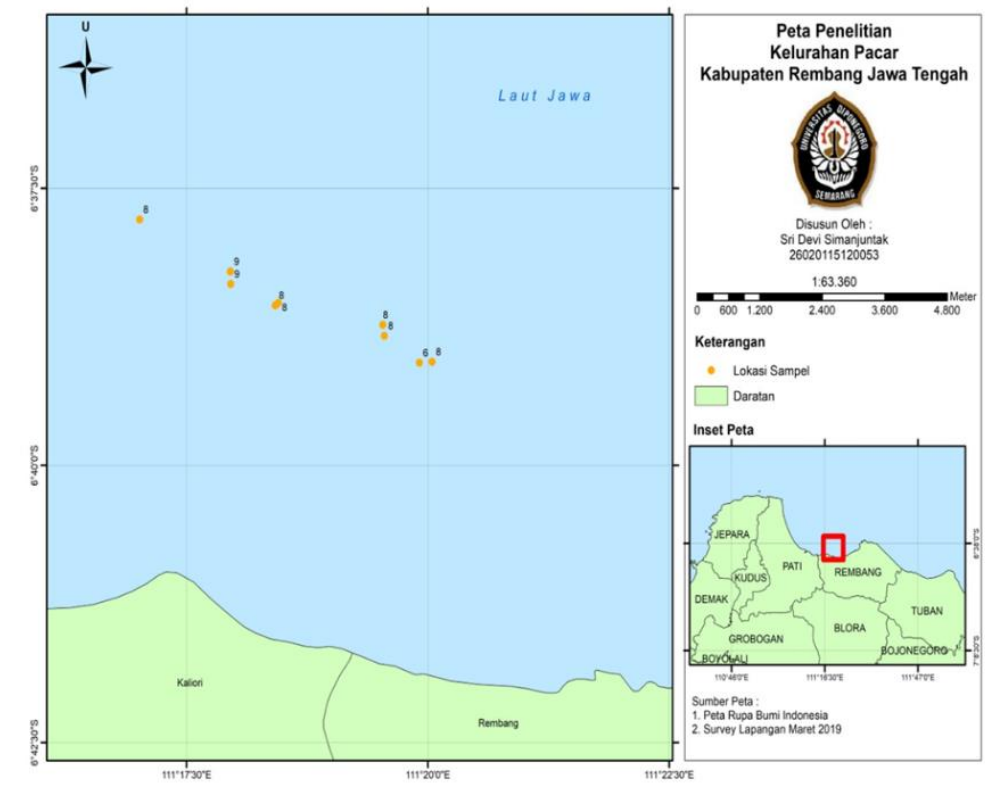

Gambar 1. Lokasi Pengukuran Parameter Kualitas Perairan

\section{HASIL DAN PEMBAHASAN}

Distribusi ukuran rajungan terbagi dalam dua kelompok, yaitu rajungan dengan ukuran $\geq 10$ $\mathrm{cm}$, dan rajungan dengan ukuran $\leq 10 \mathrm{~cm}$ disajikan dalam persentase Rajungan berdasarkan ukuran, Tabel 1 dan grafik sebarannya dapat dilihat pada Gambar 2. Dari data pada tabel dan gambar tersebut terlihat bahwa Rajungan dengan ukuran lebar karapas 100-109 mm mendominasi ukuran yang tertangkap. Distribusi frekuensi berat rajungan dan histogramnya dapat dilhat pada Tabel 2 dan Gambar 4. Rajungan yang tertangkap sebagian besar didominansi dengan berat 101108 gram.

Berdasarkan hasil penelitian distribusi ukuran lebar karapas rajungan di perairan Kelurahan Pacar, Rembang berkisar antara $60-171 \mathrm{~mm}$. Hasil selama penelitian menunjukkan 2219 ekor atau $74 \%$ rajungan yang tertangkap di perairan Kelurahan Pacar berukuran $\geq 10 \mathrm{~cm}$ sedangkan 781 ekor rajungan atau $26 \%$ masih berukuran $\leq 10 \mathrm{~cm}$. Dokumen Peraturan Menteri Kelautan Republik Indonesia Nomor 1/PERMEN-KP/2015 tentang Penangkapan Lobster (Panulirus spp.), Kepiting (Scylla spp.), dan Rajungan (Portunus pelagicus). Rajungan yang layak ditangkap dibagi menjadi dua kelompok yaitu, Rajungan berdasarkan ukuran $\leq 10 \mathrm{~cm}$ dan $\geq 10 \mathrm{~cm}$. Rajungan berukuran kecil atau kurang dari $100 \mathrm{~mm} \quad(\leq 10 \mathrm{~cm})$ wajib dilepas kembali oleh nelayan. Hal ini bertujuan untuk menjaga dan melestarikan sumberdaya rajungan di perairan dan termasuk strategi dalam pengelolaan rajungan yang sustainable atau berkelanjutan. Hasil penelitian menunjukkan masih terdapat 26\% (781 ekor) dari hasil tangkapan yang termasuk kedalam kategori rajungan

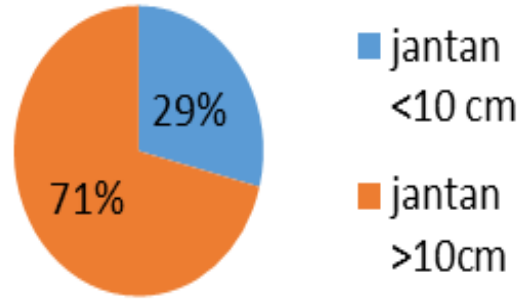

Jantan

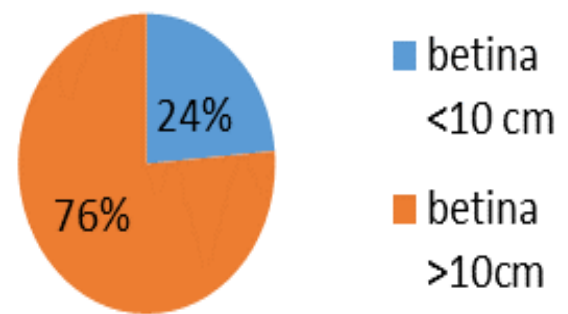

Betina

Gambar 1. Persentase Rajungan Berdasarkan Ukuran Selama Penelitian di Perairan Kelurahan Pacar 
Tabel 1. Sebaran Lebar Karapas Rajungan (P. pelagicus) Berdasarkan Ukuran Kelas di Kelurahan Pacar

\begin{tabular}{ccccc}
\hline No & Kelas (gram) & Jumlah (ekor) & Jumlah Jantan (ekor) & Jumlah Betina (ekor) \\
\hline 1 & $60-69$ & 2 & 1 & 1 \\
2 & $70-79$ & 40 & 18 & 22 \\
3 & $80-89$ & 215 & 125 & 90 \\
4 & $90-99$ & 524 & 245 & 279 \\
5 & $100-109$ & 1132 & 489 & 643 \\
6 & $110-119$ & 746 & 304 & 442 \\
7 & $120-129$ & 283 & 124 & 159 \\
8 & $130-139$ & 52 & 34 & 18 \\
9 & $140-149$ & 5 & 2 & 3 \\
10 & $150-159$ & 0 & 0 & 0 \\
11 & $160-169$ & 0 & 0 & 0 \\
12 & $170-179$ & 1 & 0 & 1 \\
\hline \multicolumn{7}{c}{ Total } & 3000 & 1342 & 1658 \\
\hline
\end{tabular}

Tabel 2. Distribusi Berat Rajungan (Portunus pelagicus) di Perairan Kelurahan Pacar

\begin{tabular}{ccccc}
\hline No & Kelas (gram) & Jumlah (ekor) & Jumlah jantan (ekor) & Jumlah betina (ekor) \\
\hline 1 & $23-41$ & 48 & 9 & 39 \\
2 & $42-60$ & 177 & 52 & 125 \\
3 & $61-79$ & 472 & 224 & 248 \\
4 & $80-98$ & 876 & 446 & 430 \\
5 & $99-117$ & 762 & 384 & 378 \\
6 & $118-136$ & 396 & 159 & 237 \\
7 & $137-155$ & 156 & 49 & 107 \\
8 & $156-174$ & 64 & 9 & 55 \\
9 & $175-193$ & 29 & 8 & 21 \\
10 & $194-212$ & 13 & 1 & 12 \\
11 & $213-231$ & 5 & 1 & 4 \\
12 & $232-251$ & 2 & 0 & 2 \\
\hline \multicolumn{7}{c}{} & Total & 3000 & 1342 & 1658 \\
\hline
\end{tabular}

yang dilarang untuk ditangkap. Nelayan di Kelurahan Pacar masih melanggar aturan dan belum muncul kejadian tentang pengelolaan penangkapan rajungan. Penangkapan rajungan dengan ukuran dibawah $10 \mathrm{~cm}$ berarti tidak mendukung pengelolaan perikanan yang berkelanjuntan karena menghambat/mengurangi rekruitmen stok pada suatu perairan. Sebaran lebar karapas selama penelitian menunjukkan, rajungan jantan dan betina yang tertangkap dengan frekuensi paling kecil didapatkan pada kisaran 170-179 mm yaitu 1 ekor rajungan betina dan 1 ekor rajungan jantan, pada lebar kelas 100 - 109 mm terdapat jumlah terbanyak yaitu 1132 ekor dengan jumlah jantan sebanyak 489 ekor dan jumlah betina sebanyak 643 ekor. Sedangkan menurut sebaran beratnya, rajungan paling banyak terdapat pada kisaran kelas 80-98 gram yaitu 446 ekor rajungan jantan dan 430 rajungan betina, sedangkan jumlah paling sedikit pada kisaran bobot 232-251 gram yaitu 2 ekor rajungan betina. Gambar 4 menunjukkan bahwa bentuk grafik batang menyerupai bentuk lonceng, yang berarti sebaran lebar karapas rajungan terdistribusi secara normal.

Hasil analisis hubungan lebar karapas dan berat $P$. pelagicus dengan persamaan $\mathrm{W}=\mathrm{aL}^{\mathrm{b}}$. Pada rajungan betina $W=0,118 \mathrm{~L}^{1,37}$ sehingga nilai $b=1,37$ yang berarti pertumbuhannya bersifat alometrik negatif yaitu bahwa pertumbuhan lebar lebih cepat daripada pertumbuhan beratnya, 
sama halnya pada rajungan jantan $W=0,114 \mathrm{~L}^{1,39}$ sehingga nilai $b=1,39$ yang berarti pertumbuhannya bersifat alometrik negatif yaitu bahwa pertumbuhan lebar lebih cepat daripada pertumbuhan beratnya. Hubungan lebar karapas dan berat rajungan digunakan untuk mengestimasi karakteristik suatu populasi dalam stok (Sparre, 1992). Selain itu dapat digunakan untuk mengetahui pola pertumbuhan rajungan (Hamid dan Wardiatno, 2015). Hasil analisis hubungan lebar karapas dan berat rajungan $P$. pelagicus baik jantan maupun betina menunjukkan hasil nilai $b<3$ dan hasil uji t square didapatkan $t_{\text {hitung }}>t_{\text {tabel }}\left(\right.$ Tolak $\left.\mathrm{H}_{0}\right)$ maka pola pertumbuhan bersifat allometrik negatif. Hasil ini menggambarkan bahwa pertumbuhan lebar karapas rajungan lebih cepat daripada pertumbuhan beratnya.

Rasio merupakan perbandingan jantan dengan betina dalam suatu populasi. Pengamatan rajungan jantan dan betina dilakukan dengan melihat morfologi rajungan yaitu dengan melihat bentuk abdomennya dan warna serta bentuk tubuhnya. Hasil selama 30 hari penelitian menunjukkan rasio rajungan jantan dan betina harian berpola fluktuatif yang artinya penangkapan rajungan di perairan Rembang bervariasi antara jantan dan betina (Gambar 7). Rasio

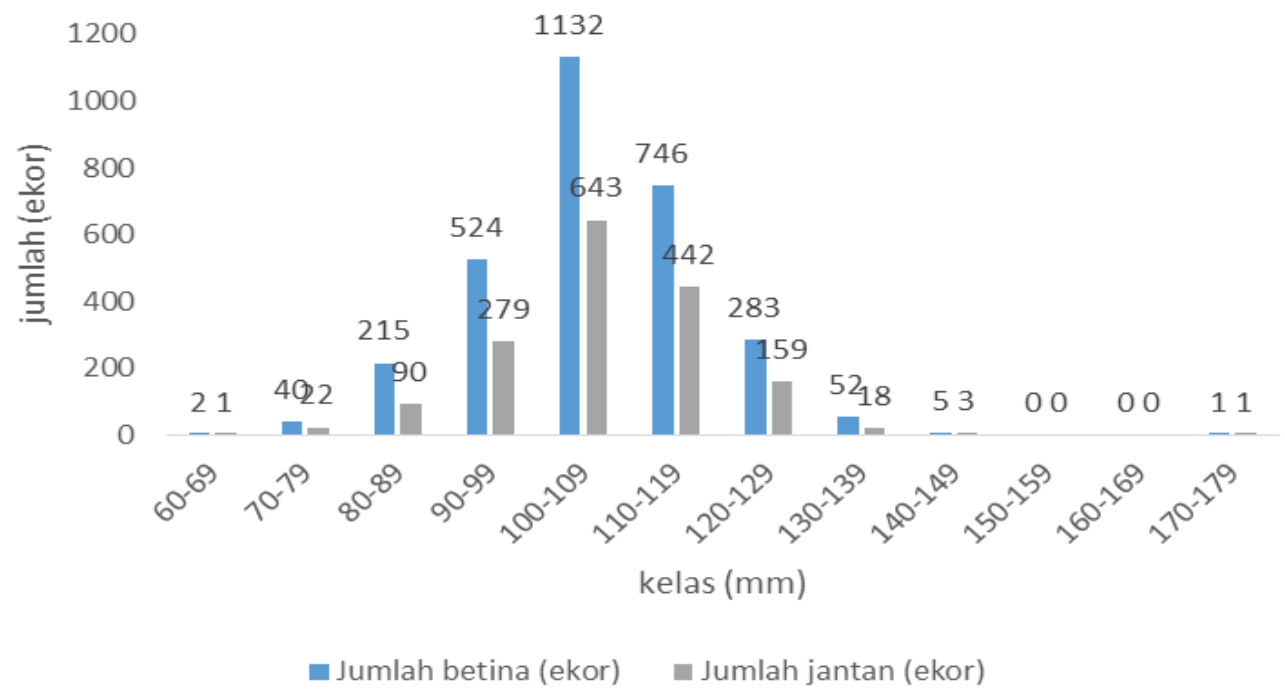

Gambar 2. Sebaran Lebar Karapas Rajungan di Perairan Kelurahan Pacar

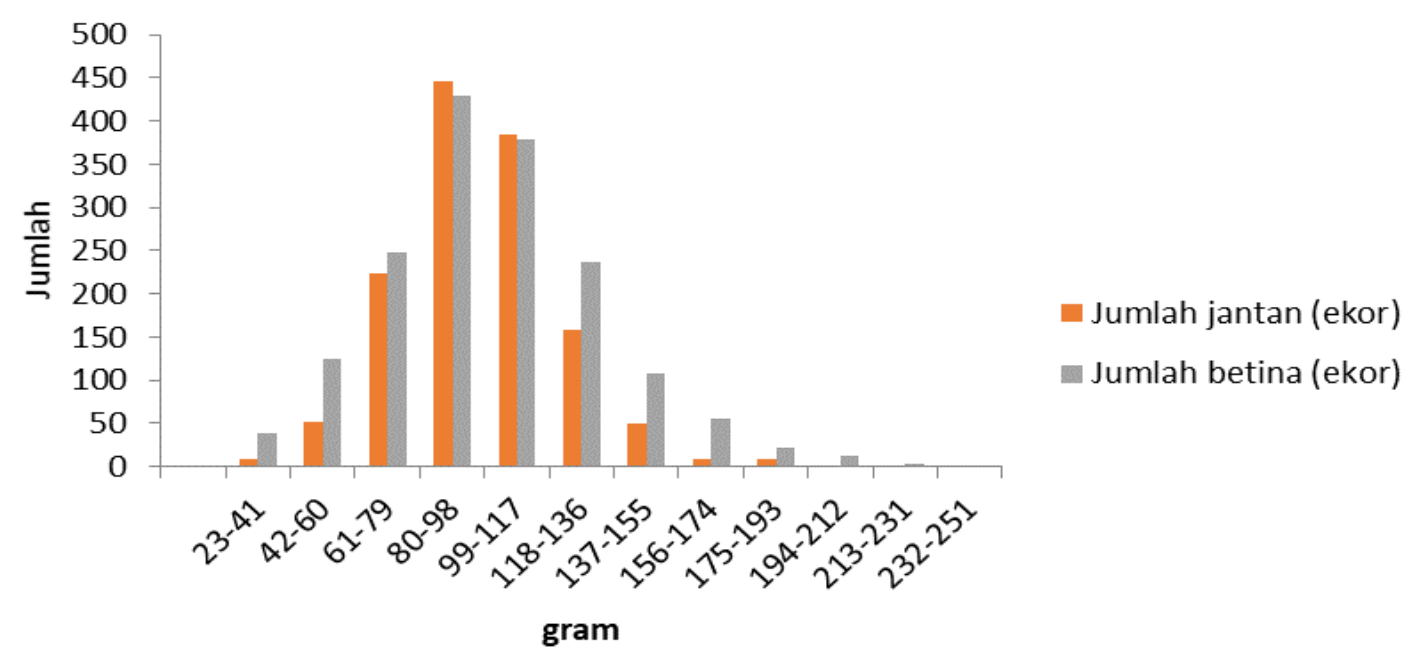

Gambar 4. Sebaran Berat Rajungan di Perairan Kelurahan Pacar 
Tabel 3. Hubungan Lebar Karapas dan Berat Rajungan (Portunus pelagicus) di Perairan Kelurahan Pacar

\begin{tabular}{ccccccc}
\hline $\begin{array}{c}\text { Rasio } \\
\text { Kelamin }\end{array}$ & $\mathrm{N}$ & $\mathrm{A}$ & $\mathrm{b}$ & $\mathrm{R}^{2}$ & $\mathrm{~W}^{2}=\mathrm{aL}^{\mathrm{b}}$ & Pola Petumbuhan \\
\hline Jantan & 1342 & 0,114 & 1,39 & 0,6065 & $0,114 \mathrm{~L}^{1,39}$ & Allometrik Negatif \\
Betina & 1658 & 0,118 & 1,37 & 0,4779 & $0,118 \mathrm{~L}^{1,37}$ & Allometrik Negatif \\
\hline
\end{tabular}

Keterangan : $a$ dan $b=$ koefisien regresi; $\mathrm{R}^{2}=$ koefisien determinasi; $\mathrm{W}=$ berat Rajungan (gram); $\mathrm{L}$ $=$ lebar karapas $(\mathrm{cm})$.

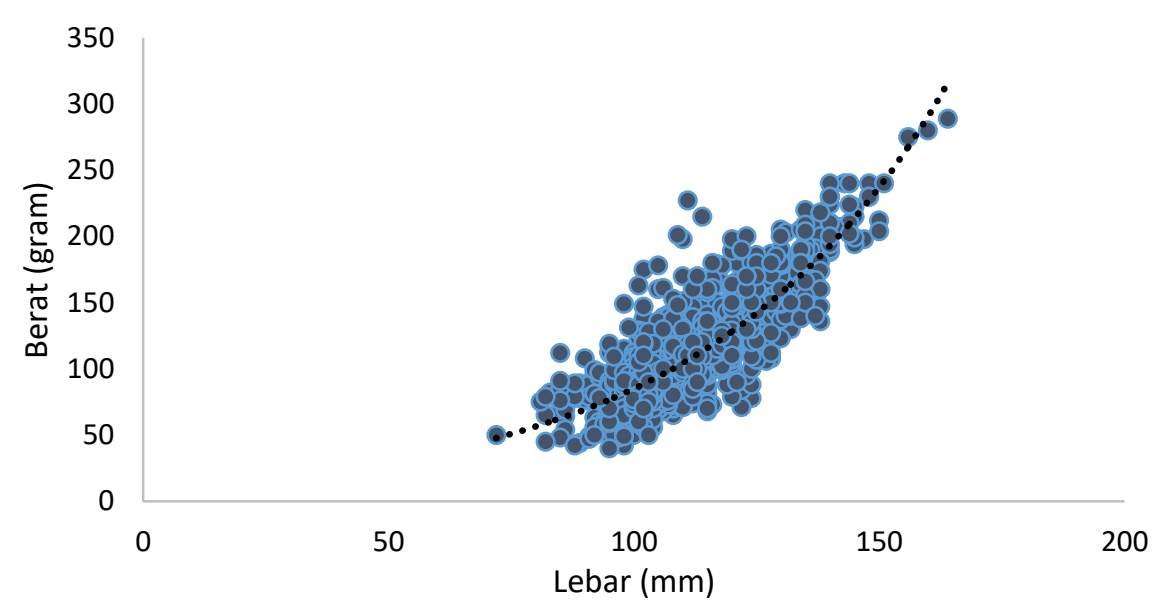

Gambar 5. Hubungan Lebar Karapas - Berat Rajungan Jantan di Perairan Kelurahan Pacar

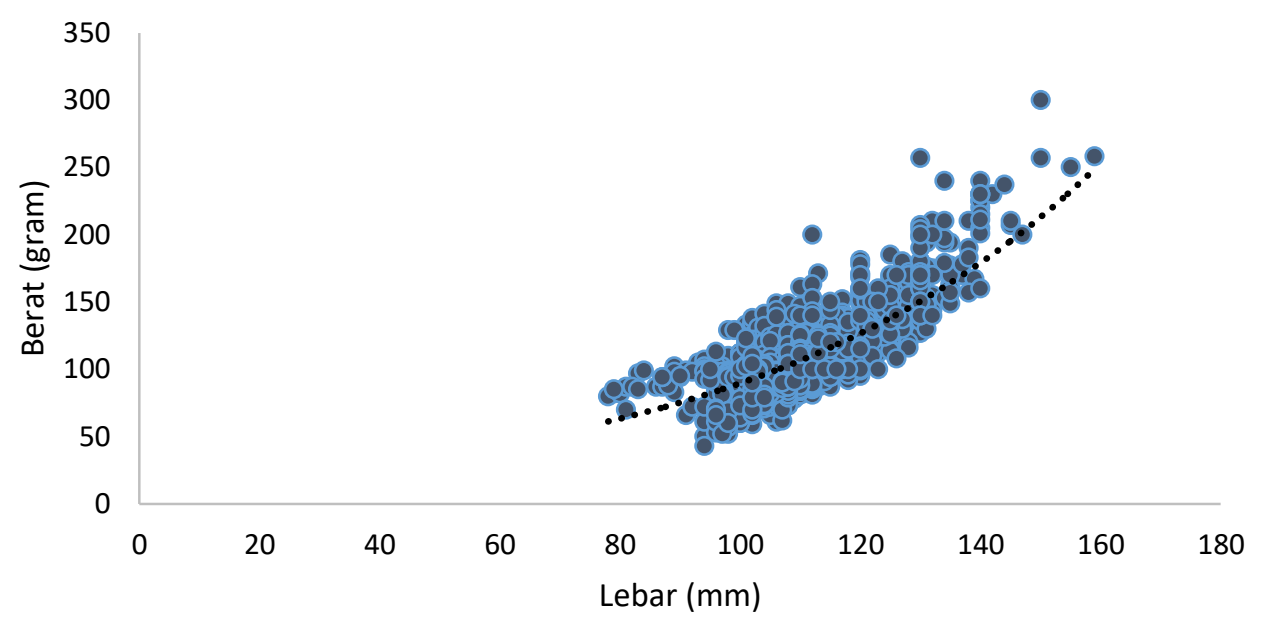

Gambar 6. Hubungan Lebar Karapas - Berat Rajungan Betina di Perairan Kelurahan Pacar

perbandingan rajungan jantan dan betina berturut turut pada hasil penelitian adalah 0,80:1. Berdasarkan Uji chi square nilai $X_{2}$ hitung sebesar 33,2 sedangkan nilai $X$ tabel 74,975 Menurut hipotesis pada Uji chi square apabila $X_{2}$ hitung $<X$ tabel maka populasi rajungan masih dikatakan seimbang. Hal ini menunjukkan bahwa jumlah rajungan jantan lebih sedikit dibanding jumlah rajungan betina. Hasil penelitian ini kemungkinan disebabkan oleh kondisi perairan. Rajungan betina dewasa lebih menyenangi habitat dengan salinitas tinggi dan perairan yang lebih dalam, sedangkan rajungan jantan lebih menyenangi perairan yang bersalinitas rendah atau perairan 
dangkal. Perubahan suhu dan salinitas di perairan sangat mempengaruhi aktivitas dan keberadaan biota laut. Menurut Kamrani et al. (2010), variasi nisbah kelamin disebabkan oleh migrasi betina pada beberapa periode dalam setahun diantaranya bulan Desember, Maret, Juli September yaitu periode pemijahan. Penelitian ini dilakukan pada bulan Maret, pada bulan Maret merupakan musim barat pada perairan. Musim barat merupakan musim berlimpahnya hasil tangkapan rajungan karena gerakan massa air atau arus yang sangat tinggi, hal ini disebabkan oleh bertiupnya angin dari arah samudra pasifik sehingga membawa berbagai zat hara yang menyuburkan perairan dan meningkatkan stok makanan rajungan dilaut (Kangas, 2000). Rasio Jenis kelamin Rajungan disajikan pada Tabel 4 dan Gambar 7 yang menunjukkan kestidakseimbangan antara Rajungan betina dan jantan.

Berdasarkan hasil penelitian jumlah rajungan betina matang gonad yang tertangkap diperaran Rembang, Kelurahan Pacar yaitu TKG 1; 34\% atau berjumlah 558 ekor, TKG 2; 46\% yang berjumlah 761 ekor, TKG 3; 20\% dengan jumlah 339 ekor. Rajungan betina yang sudah matang gonad berjumlah 339 ekor atau 22\% dari total rajungan, dilihat dari Peraturan Menteri Kelautan Republik Indonesia Nomor 1/PERMEN-KP/2015 Tentang Penangkapan Lobster (Panulirus spp.), Kepiting (Scylla spp.), dan Rajungan (Portunus pelagicus spp.), menyatakan bahwa rajungan betina yang matang gonad tidak boleh ditangkap. Rajungan yang berukuran lebih besar umumnya telah matang gonad akan bermigrasi ke perairan yang lebih dalam. Hal ini diperkuat oleh pendapat Kangas (2000), bahwa rajungan betina yang matang gonad akan banyak terdapat pada perairan yang bersalinitas tinggi (34\%o) khususnya pada daerah yang berpasir agar proses penetasan telur dapat berhasil dan mendukung perkembangan larva rajungan. Menurut Adam dan Sondita (2006), rajungan jantan lebih menyukai perairan dengan salinitas yang rendah $(28 \%$ ) sehingga penyebarannya di sekitar perairan pantai yang relatif dangkal.

Parameter lingkungan menunjukkan nilai suhu berkisar $26-30^{\circ} \mathrm{C}$. Salinitas yang didapatkan $31-$ $33 \%$. Pada pengukuran $\mathrm{pH}$ didapatkan hasil $7-8$. Kecerahan paling tinggi $2,70 \mathrm{~m}$ dan paling rendah $3,30 \mathrm{~m}$. Sedangkan kedalaman perairan yang diukur selama penelitian yaitu berkisar antara 6-8 $\mathrm{m}$. Berdasarkan data hasil pengukuran parameter lingkungan diperoleh hasil yang normal, sehingga perairan di Kelurahan Pacar, Kabupaten Rembang masih dikatakan optimal untuk siklus hidup dan tingkah laku Rajungan di perairan tersebut sehingga dapat berkembang biak dengan baik.

Tabel 4. Rasio Rajungan Jantan dan Betina (Portunus pelagicus) berdasarkan Uji Chi square

\begin{tabular}{ccccccc}
\hline \multicolumn{2}{c}{ Jumlah } & \multicolumn{2}{c}{ Nisbah Kelamin (Rasio) } & \multirow{2}{*}{$\mathrm{X}^{2}$ hitung } & \multirow{2}{*}{ X tabel $(\alpha 0,05)$} & \multirow{2}{*}{ Keterangan } \\
\cline { 1 - 3 } Betina & Jantan & Betina & Jantan & & & \\
\hline 1658 & 1342 & 1,23 & 0,80 & 33,2 & 74,975 & Seimbang \\
\hline
\end{tabular}

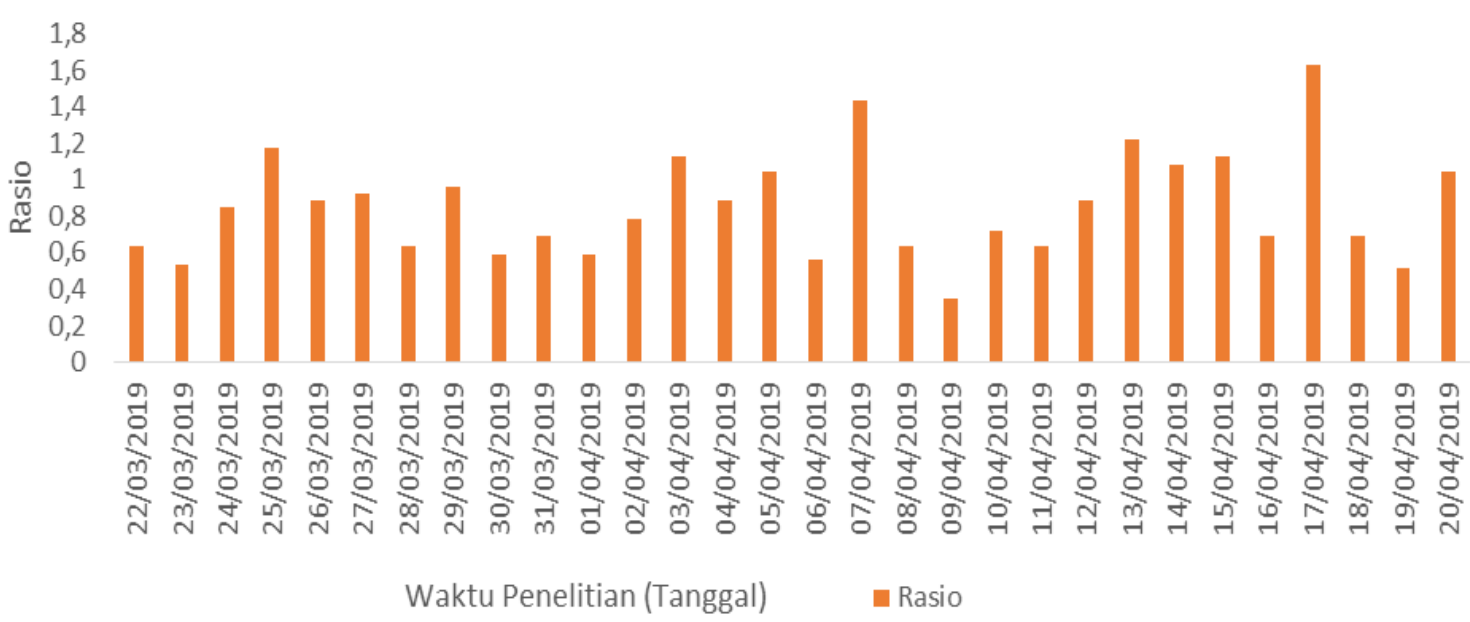

Gambar 7. Rasio Rajungan Jantan dan Betina Harian di Perairan Kelurahan Pacar 


\section{KESIMPULAN}

Berdasarkan hasil penelitian menunjukan bahwa rajungan yang berukuran $\leq 10 \mathrm{~cm}$ sebanyak 781 ekor (26\%), dan $20 \%$ memiliki TKG 3 dari jumlah betina yang didaratkan. Rajungan $P$. pelagicus memiliki kelimpahan jantan sebanyak 45\% (1342 ekor) dan betina 55\% (1658 ekor) dengan rasio perbandingan Rajungan jantan dan betina $0,80: 1$. Analisis hubungan lebar karapas dengan berat tubuh rajungan menunjukan bahwa pola pertumbuhan rajungan yang ada di perairan sekitar Kelurahan Pacar bersifat allometrik negatif.

\section{UCAPAN TERIMA KASIH}

Artikel ini merupakan bagian dari skripsi yang berjudul "Kajian Morfometri Rasio Jenis Kelamin dan Tingkat Kematangan Gonad pada Rajungan (Portunus pelagicus) yang didaratkan di Kelurahan Pacar, Kabupaten Rembang" untuk memperoleh gelar Sarjana Strata Satu Program Studi Ilmu Kelautan, Fakultas Perikanan dan IImu Kelautan Universitas Diponegoro.

\section{DAFTAR PUSTAKA}

Adam, Jaya, I, \& Sondita, M.F.A. 2006. Model bioekonomi perairan pantai (in-shore) dan lepas pantai (off-Shore) untuk pengelolaan perikanan rajungan (Portunus pelagicus) di Perairan Selat Makassar. Jurnal Ilmu-ilmu Perairan dan Perikanan Indonesia. 13(1):33-43

Asosiasi Pengelolaan Rajungan Indonesia. 2017. Panduan Pendataan Enumerator Rajungan (Portunus pelagicus). Bogor: APRI.

Badan Pusat Statistik (BPS). 2017. Statistik Perdagangan Luar Negeri ekspor 2017 Jilid I. Badan Pusat Statistik,. Jakarta.

De Lestang S., Hall N.G. \& Potter I.C. 2003. Reproductive biology of the blue swimmer crab (Portunus pelagicus, Decapoda: Portunidae) in five bodies of water on the west coast of Australia. Fishery Bulletin. 101(4):745-757.

Hamid, A. \& Wardiatno, Y. 2015. Population dynamics of the blue swimming crab (Portunus pelagicus Linnaeus, 1758) in Lasongko Bay, Central Buton, Indonesia. AACL Bioflux, 8(5): 729-739.

Juwana, S., Aziz, A. \& Ruyitno. 2009. Evaluasi Potensi Ekonomis Pemacuan Stok Rajungan di Perairan Teluk Klabat, Pulau Bangka. Oseanologi dan Limnologi di Indonesia, 35 (2):107-128

Kamrani, E., Sabili, A.N. \& Yahyavi, M. 2010. Stock assessment and reproductive biology of the blue swimming crab, Portunus pelagicus in Bandar Abbas Coastal Waters, Northern Persian Gulf. Journal of the Persian Gulf (Marine Science), 1(2):11-21.

Kangas, M.I. 2000. Synopsis of the biology and exploitation of the blue swimmer crab Portunus pelagicus Linnaeus in Western Australia. Fisheries Research Report No. 121. Fisheries Western Australia. Perth.

Kementerian Kelautan dan Perikanan. 2015. Peraturan Menteri Kelautan dan Perikanan Nomor 1 Tahun 2015 tentang Penangkapan Lobster (Panulirus spp.), Kepiting (Scylla spp.), dan Rajungan (Portunus pelagicus spp.). Jakarta (ID): Kementerian Kelautan dan Perikanan. 5 hlm.

Kementerian Kelautan dan Perikanan. 2016. Rencana Pengelolaan Perikanan Rajungan di Wilayah Pengelolaan Perikanan Negara Republik Indonesia. Jakarta: Kementerian Kelautan dan Perikanan. HIm 23

Tuhuteru \& Chodrijah, U. 2018. Parameter Populasi dan Tingkat Pemanfaatan Kepiting Bakau (Scylla serratal Forsskal, 1775) di Perairan Sebatik, Kalimantan Utara. Jurnal Litbang Perikanan Indonesia, 24(3):87-196 